\title{
International Catholic Education Studies
}

\section{A new academic and professional field develops}

\section{Richard Pring}

\section{Introduction}

It can be argued that the publication of the International Handbook of Catholic Education (IHCE) in two volumes, edited by Gerald Grace and Joseph O'Keefe SJ in 2007, marked the first ever summary of the challenges facing Catholic education in over thirty countries. IHCE was the outcome of a five-year project, jointly sponsored by the Centre for Research and Development in Catholic Education in London (which Grace founded in 1997) and the Lynch School of Education at Boston College, USA (of which O'Keefe was dean). One of the major challenges identified at the time was the growing influence of secularisation and of secularism, especially in the West. As the editors explained it:

Secularism represents the denial of the validity of the sacred and of its associated cultures. It affects the worldview of many people to the religious concepts, religious discourses and religious sensitivities are regarded as simply irrelevant to the everyday business of life... if secularisation in the West presents Catholic schools and colleges with the challenge of indifference, the ideology of secularism presents stronger challenges. Secularism, in educational terms, represents an active and hostile stance towards the existence of faith-based schooling and education of all types.

(Grace \& O’Keefe, 2007, pp. 2-3)

In 2009, Grace launched the journal International Studies in Catholic Education, one of the purposes of which was to monitor, by research and academic and professional scholarship, the growing impact of secularisation and of secularism on Catholic schools across the world. The journal, accessed in 2020 in 112 countries, plays a crucial role in monitoring these challenges and the responses being made to them by Catholic and other faith educators.

DOI: $10.4324 / 978|003| 7 \mid 553-5$ 


\section{Vatican II and education}

The importance of the Centre and the journal arose partly as a result of the developments in the Church, following the Second Vatican Council (1962-1965), which made several significant proposals about the religious purpose, ethos and curriculum of its Catholic schools. There was to be greater openness to the broader religious, as well as secular, ethos beyond that traditionally sustained by Catholic education. In England certainly, the establishment of Catholic schools had been a determined policy by the Church, following the establishment of the Catholic hierarchy in 1850, to support and protect the many poor Irish immigrants who were escaping from the famine. The school was part of the parish, helping its members (so many of them poor) and providing a protective community (materially and spiritually) in an often alien world.

The emphasis of Vatican II, however, was one of the Catholic school being more missionary - to be spreading more widely the Gospel message. According to Flannery in his report on Vatican Council II: The Conciliar and Post Conciliar Documents (1998), a more open and liberal mode of Catholic schooling was to be promoted.

It is... the special function of the Catholic school to develop in the school community an atmosphere animated by a spirit of liberty and charity based on the Gospel. It enables young people, while developing their own personality, to grow at the same time in that new life which has been given them in baptism... Accordingly, the Catholic school can be of such service in developing the mission of the People of God and in promoting dialogue between the Church and the community at large to the advantage of both, it is still of vital importance.

(Quoted in Grace, 2002, p. 17)

The key document, therefore, emerging from the Council with regard to education was Gravissimum Educationis, in 1965, with special emphasis on preparing young people, upon their graduation, for a much more secular society, not just to survive religiously within it but also to help transform it into the world heralded by the Gospels, which of course would include an emphasise 'Caring for the poor, for those who are without help and affection of family and those who do not have faith' (par. 10). Indeed, following Vatican II, there was a changed conception of the Catholic school as one which should be open to members of society who were not of the Catholic Faith but who might be transformed by the spiritual ethos and humanitarian concerns of the Catholic school. Such schools were increasingly seen, therefore, to have a more open missionary spirit, not simply one of nurturing the Faith within the Catholic community, as, for example, can be seen in the later document published by the Catholic Bishops of England and Wales in 1997, called simply The Common Good in Education. 
There are a number of key documents from the Vatican Congregation for Catholic Education following from the second Vatican Council, and from the Catholic education authorities in the different countries, but the general message remained constant and was articulated well by Pope John Paul II in 1994 as follows.

Against the spirit of the world, the Church takes up each day a struggle that is none other than the struggle for the world's soul. If in fact, on the one hand, the Gospel and evangelisation are present in this world, on the other there is also present a powerful anti-evangelisation which is well organised and has the means to vigorously oppose the Gospel and evangelisation. The struggle for the soul of the contemporary world is at its height where the spirit of the world seems strongest.

(quoted in Carr, 1999, p. 173)

But statements and recommendations concerning such a struggle were necessarily pitched at a fairly abstract level. Their significance and implementation required much thought and deliberation, reflecting the different national circumstances and challenges, and requiring sensitivities to those different religious and national circumstances as well as systematic empirical research into the distinctive school systems.

This chapter now moves on to describing the wider sociopolitical context against which this Catholic vision for education exists, in particular the secular paradigm which dominates. It is in this context that market forces have come to have a deeply distorting effect on education. It is this difficult situation that Grace's work has repeatedly drawn attention to.

\section{Changing context}

The early 19th century saw the beginning of the national system of education when a Christian background culture was generally taken for granted and religious teaching was based on Christian foundations. But such an assumption was gradually undermined by an increased secular culture, where religious belief could no longer be taken for granted and was increasingly treated with some hostility. The Secular Education League was formed in 1907, arguing that 'teaching of religion was not the responsibility of the State' and should not be subsidised by the rates. It called for a 'national system of education, elementary and advanced, free and secular, and under complete secular control' (Justice, April 1908).

Emile Durkheim (1961, pp. 48-49) spoke thus of such changes in France:

The last twenty years in France have seen a great educational revolution which was latent and half realised before then. We decided to give our children in our state-supported schools a purely secular education [that is, 
an education] not derived from revealed religion, but that rests exclusively on ideas, sentiments and practices accountable to reason alone - in short, a purely rationalist education.

Such a secular view continued to exercise its influence, reflected in Lady Olga Maitland's speech in the British Parliament's House of Commons in 1962, when she declared that 'the time has come to stop being apologetic about being a Christian country, we should not allow unbelievers to undermine our traditions'.

A part solution to the problems had been suggested in 2018 by the Commission on Religious Education (CoRE) for England and Wales, which reviewed the legal, education and policy framework for religious education to be studied up to the age of 16, to inform policy-makers and 'to prepare pupils for modern life in Britain'. Significantly, it recommended that the subject should be renamed as Religion and World Views, the content of which

...must reflect the complex, diverse and plural nature of world-views drawing from a range of religious, philosophical, spiritual and other approaches to life, including different traditions within Christianity, Buddhism, Hinduism, Islam, Judaism, and Sikhism, non-religious world-views and concepts including humanism, secularism, atheism and agnosticism.

(CoRE, 2018, p. 11)

To this the Catholic Education Council responded in a critical way that it is 'Not so much an attempt to improve religious education as to fundamentally change its character. The quality of religious education is not improved by teaching less religion' (quoted in Whittle, 2020, p. 363).

Against these differing perceptions of religious education, it is important to ask what could be meant by 'religious character' or indeed the 'teaching of religion'? To teach a subject in an educational context is to initiate someone into a way of thinking, of appreciating, of seeing things from a different point of view. It is what Matthew Arnold referred to as the cultivation of the intellect, the insight into a cultural inheritance through which one comes to appreciate the world and one's life differently. Just to learn a few propositions about one of several religious and non-religious views of life quite clearly fails to do that. The appreciation of religion, therefore, as a way of life built on a long tradition of beliefs, which have been philosophically explored and which are expressed practically through the liturgy, requires much more careful nurturing, as will be illustrated below.

Meanwhile, one needs to be aware of the changes to religious practice partly, no doubt, arising from the failure to provide insight into a religious way of life, supported by liturgical practices and the cultivation of the religious insight. Within this more secular society and the failure to provide a solid foundation for the beliefs which would underpin religious education, there has been a revolutionary decline in the proportion of young people experiencing or 
participating in religious practice and worship. According to the British Social Attitude Survey (BSA, 2018), less than 2\% of 18-24 year-olds now identify with the Church of England which, being the National Church, has maintained the importance of religious education in all schools. That is against the background of a general decline of the population in religious practices and commitments since the previous survey in 1983 , according to which there was a decline from $66 \%$ to $38 \%$ of those identifying themselves as Christian; those claiming no religion rose from $31 \%$ to $52 \%$; the number of Britons identifying themselves as Church of England or Anglican dropped from $40 \%$ to $14 \%$; amongst that number, but under age 24 , that figure is no higher than $2 \%$; those claiming to be Catholic reduced from $10 \%$ to $7 \%$. The majority of the population say that they have no religion. Similar problems have arisen in the once fervently Catholic Ireland. An article in the Tablet entitled 'Ireland's Vanishing Church', reported 'That schools are dropping religious education, vocations are drying up, and lay people are not being prepared to take more responsibility for the maintenance of parishes. The Irish Church faces a bleak future' (Cotter, 2018, p. 28).

However, secularisation has come to signify more than indifference to religion, but rather the view that there is a contradiction between a 'confessional education' and one based on reason, clearly put by Professor Paul Hirst: 'There has already emerged in our society a view of education, a concept of education, which makes the whole idea of Christian education a kind of nonsense and the search for a Christian approach to, or philosophy of, education a huge mistake' (1972, p. 6). This something that Pope John Paul II has drawn attention to (quoted above): 'If in fact, on the one hand, the Gospel and evangelisation are present in this world, on the other there is also present a powerful anti-evangelisation which is well organised and has the means to vigorously oppose the Gospel and evangelisation. The struggle for the soul of the contemporary world is at its height where the spirit of the world seems strongest'.

The Catholic Church, therefore, especially through the way of life and the teaching within its schools, has a major task in the 'struggle for the soul of the contemporary world'. In the following section, this chapter will outline in greater detail the characteristics of that contemporary world, before daring then to suggest possible ways forward in re-invigorating its very different conception and way forward.

\section{A secular society}

Given the changes described above, Charles Taylor (2007) contrasts two very different ways in which modern society has come to perceive the purposes and values which shape our ways of living, especially the different values as to what constitutes personal well-being. He refers to them as different 'horizons of significance', each of which reflects or incorporates beliefs about the world, the values which are seen to be worth pursuing and most obviously whether or not 
life has a spiritual and religious significance. The secular 'horizon of significance' in the 'post-religious revolution' may be exemplified by very different understandings of sexual relations and marital commitments, by the undermining of virtues (for example, 'modesty') which were part of the religious mode of living, and by the dominant search for material satisfaction and economic profit. For example, as Keith Joseph, founder of the influential think-tank Centre for Policy Studies, affirmed in 1976:

The blind, unplanned, uncoordinated wisdom of the market is overwhelmingly superior to the well-researched, rational, systematic, wellmeaning, co-operative, science-based, forward-looking, statistically respectable plans of government.

$$
\text { (Joseph, 1976, p. 3) }
$$

As Copley (2005, p. 34) expressed it, 'economics has become the theology of a materialist society'.

The 'market' was injected into educational policy and practice. Indeed, the role of 'the market' in raising standards in State schools, was strongly advocated by the Centre for Policy Studies, the leading right-wing think-tank, founded by Sir Keith Joseph and Margaret Thatcher in 1974 to develop a new generation of Conservative thinking, built now on promoting enterprise, profit and ownership. With regard to schools, this would be helped by extending parental choice of schools, assisted by schools' greater accountability in terms of targets in order to provide evidence for such choice. There would be greater autonomy of schools, encouraged by parental choice within the more marketised system and supported by the public evidence arising from the 'national assessment of performance'. It is the recognition of the damaging effects of the market which has been a central preoccupation in the work of Gerald Grace. In more recent years, other eminent voices have drawn attention to the danger within market-based ideology. For example, Pope Francis in Evangelii Gaudium speaks of the need for us to assert human values in the face of a market system (this author's italics) which has become an 'an economy of exclusion and inequality'.

One further, if connected, aspect of the very different 'horizon of significance' in the more secularised society is what one might refer to as the 'depersonalisation' enforced by the increased 'managerialism', especially apparent in the context of 'schooling'. There we see the narrowing of educational success to attainment of targets within the ever-changing qualifications systems. Gone would seem to be the 'form of the personal' (to use John MacMurray's words from his influential Gifford Lectures in 1957) and gone would be the wider understanding of what it means to be and to develop as a person, which is central to the very different 'horizon of significance' promoted through religious belief and practice. 


\section{The challenges facing Catholic education}

In the light of the market forces which Gerald Grace's work has drawn attention to, the concluding part of this chapter will offer some proposals about the important role that Catholic education has to play in pointing beyond this secular context towards the sacred or numinous and spiritual in the world.

One can see, therefore, how the Catholic school should be seen as central to what Pope Francis referred to as part of the struggle for the soul of the contemporary world, engaging with young people, most of whom (though by no means all) would be practising members of the Church, many others only loosely so, and others too of other religious beliefs (for example, the many Muslims who attend). In such a mixed 'congregation' it is important to see how the Faith can be seen as relevant and the basis for discussion, enlightenment and commitment. In what follows there are suggested several ways in which the Catholic school might meet the demands of Pope Francis to support 'the struggle for the soul of the contemporary world'.

In terms of Catholic education, the Church should be seen as offering an ideal of a contrasting view of society, in which the idea of personal development for all students (not just the academically able) would be central, and which would be embodied in the curriculum, and open to systematic deliberation by all, whether believers or not. A significant part of that ideal would be an account of the Catholic Church's teaching of the 'Common Good' as detailed in Leo XIII's encyclical Rerum Novarum in 1879 , but with special reference to the moral teaching of the Church, recognising the dignity of each member of society, irrespective of religious or social background, and with special reference to the poor and disadvantaged, as stated by the Congregation for Catholic Education (CCE): 'First and foremost the Church offers its educational service to the poor or those who are deprived of family life and affection or those who are far from the faith' (1977, par. 58). The contrast between such an idea, inspired by traditions of the Church, would most likely challenge semi-conscious beliefs and understandings of the students, whether Catholic or not.

\section{Pointing to the sacred or numinous or spiritual in the world}

It would be important for all pupils, firm believers or not, to appreciate how, underlying the beliefs and practices of the Church, there is a sense of 'the sacred' or 'the numinous', which can be recognised through poetry, literary accounts, the arts especially music - and enhanced, if properly conducted, through the liturgy of the Church. One might reflect here upon parts of Bach's St. John Passion or Faure's Requiem (especially the Pie Jesu, which I sincerely hope will be sung at my Requiem Mass). But this sense of the sacred is shown in much poetry - that, for example, of Gerald Manley Hopkins as in his poem God's Grandeur, where he reveals what he sees to be the permeating presence of the divine in surrounding nature, despite 'man's smudge': 
The world is charged with the wonder of God

It will flame out, like shining from shook foil;

Or again, as William Wordsworth writes in Tintern Abbey of 'a presence that disturbs me with the sense of elevated thoughts; a sense sublime of something far more deeply inter-fused whose dwelling is the light of setting suns'.

Such references and also many more are explored by Otto in The Idea of the Holy where he concludes that the idea of the holy is a primary datum of consciousness, but can only 'be evoked, wakened in the mind: as everything that comes of the spirit'. As he points out, such consciousness is to be evoked through the lives of holy men and women, through the displays of spiritual lives of religious people, in their rites and liturgies, and in the manifestations of religious piety and worship which have been inherited. In pursuing this development of the spiritual consciousness, the teacher would no doubt benefit from the accounts by William James in his classical study of The Varieties of Religious Experience, or by Eric Robinson's The Original Vision: A Study of the Religious Experience of Childhood.

It would be important to show how such spiritual consciousness is maintained in very different religious traditions. As Hossein Nasr (1987, p. 195) explains,

The sacred art of Islam is, like all veritable sacred art, a descent of heavenly reality upon earth. It is the crystallisation of the spirit and form of Islamic revelation dressed in the robe of a perfection which is not of this world of corruption and death.

Having a spiritual perspective on life, deeply questioning the materialism which permeates our culture, would provide a basis for, and an introduction to, the distinctive contribution of Catholic schools to the 'struggle for the soul of the contemporary world'.

\section{Recognising a spiritual dimension to living}

As Gerald Grace (2002, p. 34) argues in his paper entitled 'The renewal of spiritual capital and the critique of the secular world', such awareness can arise even amongst those of little faith from consideration of the Gospel stories or accounts of the achievements of holy people or from attention to parts of the liturgy, which themselves are but the expressions and manifestations of spiritual awareness. And the development of such awareness may not be confined to the Christian liturgy. Listening to and witnessing the Muslim call to prayer or experiencing the Jewish rituals, which have persisted and inspired the Jewish race for several millennia, would create an awareness of what the Chief Rabbi Jonathan Sacks (1997, p. 51) referred to as 'a morality received not made... embedded in and reinforced by a total way of life, articulated in texts, transmitted across the generations, enacted in rituals, exemplified by members of the community and underwritten by revelation and tradition'. 
The spiritual dimension arises from the gradual awareness of there being something deeper in our relation to the world and to other people than what is immediately apparent through the senses - a view of human destiny which transcends the material world and which is captured within different religious traditions. An educational programme should reveal the meaning of such traditions and the ways in which they provide a background to the lives deemed to be worth living.

\section{Making sense of morality and the demands of conscience}

It is important to reflect upon the phenomenon of 'conscience', that 'inner voice' which warns one, with varying degrees of severity, that certain intended actions are wrong. To live a distinctively human life requires the recognition of right or appropriate actions in particular circumstances - not telling lies, not offending or hurting one's neighbour, accepting obligations to friends and acquaintances, honouring promises. That strong sense of obligation and duty suggests, according to the philosopher Immanuel Kant, the postulation of a Supreme Spirit as the author of the moral obligations and the sense of duty.

\section{Philosophical engagement with such claims}

Education, particularly Catholic education, is centrally concerned with the development of reason in its different forms, and the validity of religious claims to knowledge would therefore be one such form to be investigated. To what extent is it reasonable to hold and be committed to religious beliefs and ways of life? And in answering such a question, there would be a need to answer questions about the nature, meaning and validity of key arguments. First, however, it would be important to recognise that the Church has been the custodian of a very long philosophical tradition which has shaped its understanding of the Faith, and which thrives to this day amongst leading philosophers. Part of the religious education of young people within the Church's schools, whether active members of the Church or not, would be for them to be aware of such a tradition, going back to the very early Christianity and beyond to the influence of the Greek philosophers. The basic tenets of such a tradition might be offered for discussion, though doubtless rejected by some. One is thinking here of how to put across the various arguments from causality - efficient or final - respected by major philosophers. But this would be conducted within what Martin Lipman (2003) referred to as a 'Community of Inquiry', encouraging informed discussion rather than the 'acquisition of received knowledge', informed by examples of relevant philosophical thinking but open to objections and clarification.

It is crucial here not to be too demanding on 'proof' as that is so often conceived in the light of mathematical or scientific forms of reasoning and knowledge. As with much of our knowledge and rational appraisal of life, strict proof is not possible - either, for example, that God exists or that God does not exist, 
either that it is right to tell the truth or wrong not to do so. Most of the important elements in living (for example, the values to be respected or the sort of life to be pursued) are open not so much to proof but to deliberation based on evidence presented, and through experiences and criticisms which support particular beliefs and understandings. That is true of the philosophical arguments for a spiritual and religious dimension to life which have entered into the Christian tradition from the inheritance of the Greek philosophers and have evolved ever since.

What Catholic schools should do is to introduce the pupils to these deeply based traditions in order to ensure at least a sense of the ideals which are part and parcel of the Christian (and indeed other) religious traditions, a sense too of the sacred and numinous, a feeling for the spiritual dimension to living, and consideration of the formation and refinement of conscience with its distinctive religious character. And, where possible (depending on the age of the pupils), an introduction to the philosophical arguments, developed over the centuries, would do no harm!

\section{A way of proceeding}

Open and free discussion of the issues, outlined at the beginning by the teacher, should be encouraged, with the different viewpoints - whether orthodox or not expressed and opened to discussion. Strict rules would be required concerning respect for the different speakers and their views, though open to opposition based on evidence and argument. It would help, of course, if for each topic short texts would be distributed (for example, brief philosophical texts but with indications where the arguments may be pursued further). Being open to spiritual, scriptural, philosophical and theological accounts would seem to be essential to a deepening understanding of, and eventual commitment to, a religious tradition.

\section{References}

British Social Attitudes (BSA), (2018). British Social Attitudes Survey, https://bsa.natcen. ac.uk.

Carr, D., (1999), 'Catholic Faith and Religious Truth', in Conroy J, (ed.) Catholic Education: Inside Out, Outside In, Dublin: Lindisfarne Books.

Catholic Education Service, (1997). The Common Good in Education, London: CES.

Commission on Religious Education (CoRE), (2018). Religious Education for All, London: Religious Education Council for England and Wales.

Congregation for Catholic Education, (1977). The Catholic School, Vatican website, last accessed 9 October 2020.

Copley, T., (2005). Indoctrination, Education and God, London: SPCK.

Cotter, B., (2018). 'Ireland's Vanishing Church', The Tablet, 22 August 2018, www.theta blet.co.uk/features/2/14213/ireland-s-vanishing-church

Durkheim, E. (ed.), (1961). Moral Education: A Study in the Theory and Application of the Sociology of Education, New York: The Free Press. 
Flannery, A., (1998). Vatican Council II: The Conciliar and Post Conciliar Documents, Vol.1, New revised edition, New York: Costello Publications.

Grace, G., (2002). Catholic Schools: Missions, Markets and Morality, London: Routledge.

Grace, G. \& O'Keefe, J. (eds), (2007). International Handbook of Catholic Education (2 volumes). Dordrecht: Springer Publications.

Hirst, P., (1972). 'Morals, Religion and the Maintained School', British Journal of Educational Studies, 14, pp. 5-18.

James, W., (1902). Varieties of Religious Experience, London: Gifford Lectures.

Joseph, K., (1976). Stranded on the Middle Ground, London: Centre for Policy Studies.

Lipman, M., (2003). Thinking in Education, Cambridge: Cambridge University Press.

Macmurray, J., (1957). Self as Agent, London: Faber and Faber.

Nasr, S.H., (1987). Islam, Art and Spirituality, Lahore: Subhail Academy.

Robinson, E., (1977). The Original Vision: A Study of the Religious Experience of Childhood, Oxford: Manchester College.

Sacks, J., (1997), The Politics of Hope, London: Jonathan Cape.

Taylor, C., (2007). Secular Age, London: Harvard University Press.

Whittle, S. (2020). 'An Evaluation of the Catholic Response to the Final Report from the Commission on Religious Education', Journal of Religious Education, pp. 359-369. 